\title{
21st CENTURY ENGINEERING CHALLENGES OBSERVED THROUGH COMPUTER VISION SYNDROME
}

\author{
Dejan Viduka, Marina Dragičević, Ana Bašić, Biljana Viduka, Igor Lavrnić
}

Preliminary communication In the beginning of the new millennium, professional engineering cannot be imagined exclusive of the use of computers. Engineers who use computers or some other monitoring display terminals, both in design and various manufacturing phases, have been exposed to the effects of computer vision syndrome. Computer has become almost an indispensable piece of equipment both in the office and at home. This paper defines the computer vision syndrome, describes its genesis and explains related consequences. In the central part of this paper, results are presented of the research conducted in the Republic of Serbia regarding computer users, detected computer vision syndrome symptoms as well as the genuine actuality of computer vision syndrome among computer users. The final part of the paper offers possible solutions for reducing the effects and preventing occurrence of the observed syndrome.

Keywords: Computer Vision Syndrome - CVS; engineering work; eye morphology; personal computer (PC) - display and visual aid

Izazovi inženjerstva u 21. stoljeću promatrani kroz sindrom računalnog oka

Prethodno propćenje Inženjerski posao početkom novog tisućljeća više se ne može zamisliti bez računala. Inženjeri koji u svom radu koriste računala ili neke druge ekrane za promatranje, kako za projektiranje, tako i u fazama rada u proizvodnji, izloženi su utjecaju sindroma računalnog oka. U ovom radu definiran je sindrom računalnog oka, objašnjen je njegov nastanak i izložene su njegove posljedice. U središnjem dijelu rada dani su rezultati istraživanja provedenog u Republici Srbiji o pitanju poznavanja korisnika računala, uočenim simptomima ovog sindroma i postojanju sindroma računalnog oka. Na kraju rada izložena su rješenja za smanjenje i sprječavanje nastanka promatranog sindroma.

Ključne riječi: inženjerski posao; morfologija oka; sindrom računalnog oka - CVS; zaslon računala i očna pomagala

\section{Introduction}

Computer use has become a vital part of work and life of many people, especially engineers. Computer has become an almost indispensable piece of equipment both in the office and at home. Creation of computers has caused a revolutionary turnaround in the society so that it is today actually impossible to measure the advantages of the computer use in numerous and various fields of operation. However, observed from a medical point of view, excessive use of computers has caused occurrence of an array of health-related issues [1].

In spite the fact that computers make work easier and more efficient, their frequent use has significant effects on users' health. According to the American Optometric Association - AOA, almost 70 $\div 75 \%$ of computer users have eyesight problems, known as the Computer Vision Syndrome- CVS.

Frequent use of computers is associated with various health issues, such as: eye sensitivity to flash, eye dryness, excessively watery eyes, eye redness, headache, neck pain, sleepiness, focus difficulties, heavy eyelids, contact lens related discomfort, changed perception of colors and similar. All the above mentioned symptoms are collectively named - the computer vision syndrome. This syndrome comprises eye anomalies or extra ocular accommodation spasms (musculoskeletal symptoms), accommodative mechanism disorders (blurring of vision, double vision, presbyopia, myopia and slowness of focus change) and ocular surface mechanism problems (dryness of the eyes, redness and gritty sensations). All the above mentioned symptoms are related to individuals lacking visual capacities to complete given computer tasks comfortably $[2 \div 4]$.

\section{Defining problems and causes}

Computer vision syndrome is defined as eyestrain associated with prolonged use of computers. The American Optometric Association, which introduced the CVS term into the medicine, gives a broader definition according to which this syndrome includes eye problems and vision related issues with computer users who spend much time in front of computer display terminals. Even if such an individual has all the normal vision prerequisites, the two or more hours spent working on a computer or in front of another display, increase the possibility of obtaining some of the CVS related problems.

The reason behind CVS is more than simple: on the one hand there is continual everyday improvement of the technology, and on the other hand there is the fact that eye morphology has not changed in thousands of years. That is why human eye is not capable of watching the display of a computer or of another electronic unit for a long period of time, as modern jobs require it. This problem could jeopardize companies' business operations continuity in case their leading experts suffer from CVS. Focusing the eye on a display is more demanding than reading of hard copies. As it is well known, the display image consists of thousands of small dots - pixels. These dots have a clear center but blurring edges, which presents a huge problem for proper eye focusing. That is why the eye, striving to maintain clear vision, becomes tense and eye muscles strain. In addition, computer vision is also affected by resolution, flashing and reflection of the display [5:7].

Numerous research studies conducted in this area show that eye blinking frequency during computer work is significantly reduced, being even five times fewer. 
Reduced eye blinking can cause eye dryness, eye redness and irritation due to faster tear film evaporation.

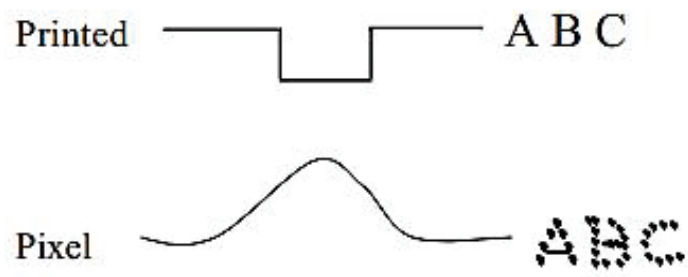

Figure 1 Display and hard copy depictions [12]

Some causes of the CVS occurrence include the following: poor lighting, reflections from the screen, nonoptimized distance between the eye and display screen, improper sitting posture during work, existing vision problems as well as combination of all above mentioned factors.

Although, for the time being, there has been no reliable proof linking intensive computer use with permanent eye damage, the stated symptoms can indicate serious health issues.

According to the American Optometric Association AOA, only $14 \%$ patients turn to ophthalmologists for help due to CVS, while majority of computer users remain unaware of the causes of their vision problems.

The capability of an individual to recognize the CVS often depends on the level of the individual's visual capabilities as well as on the time that individual spends in front of the display. Moreover, uncorrected vision problems such as farsightedness, astigmatism, inadequate eye focusing or coordination, aging and eye alterations (such as farsightedness) can additionally contribute to CVS symptoms development, especially with persons who use computers in long time intervals $[8,9]$.

\section{Promising future profession}

It is often heard that taking an IT profession is a wise decision for the future, promising good earnings, so lots of parents advise their children to continue their education in this direction. This is a true statement, no doubt, but this topic should also be observed from the standpoint of the computer eye syndrome and the difficulties that go along with it.

In fact, every educated engineer, but primarily an IT expert (as in IT profession computer is an essential tool and not just an accessory), after completing his/her education and starting to work in the profession, expects a career of 40 years. This is very challenging in terms of the health of users who spend minimum eight hours at the computer (around 84480 hours during their working life).

\section{Current situation in Serbia}

It can often be heard in the media that Serbia is in demand of thousands of new IT specialists (programmers) and that this lack delays coming of foreign companies to the local market. This statement is probably true, but when we talk about the quantity of lacking experts, this figure should also include the number of those IT specialists who in time lose their work capabilities due to CVS.

\section{Research methodology}

The research conducted for the needs of this study was carried out using an electronic questionnaire. The electronic questionnaire was attached to a particular Internet address which the paper authors sheared on social networks and professional forums, gathering numerous users who operate computers for business and other purposes.

The questionnaire was designed in such a way that the examinee first provided basic information such as gender, age and occupation, followed by questions about the use of computers and their opinion regarding this research. All the questions in the questionnaire were obligatory and only answering to all the questions made the examinees eligible to return the questionnaire to the authors' e-mails. The protective method used was Captcha, i.e. the response of the system designed to prevent spam robot from filling in the questionnaire on its own thus affecting validity of the obtained results.

\section{Discussion of the results}

The total of 90 examinees (65 men and 25 women) took part in the conducted research, out of which more than a half $(58 \%)$ were over 30 years of age. Half of the examinees did not use any eye aids, while more than a third of them $(36 \%)$ used eyeglasses. Very few examinees used lenses $(6 \%)$ and artificial tears $(5 \%)$. In addition to these data, Tab. 1 clearly depicts that more than a third of the examinees $(17 \%)$ spent eight hours in front of the display, and (28\%) of them spent more than eight hours per day in front of the computer.

Table 1 The research results

\begin{tabular}{|c|c|c|c|c|}
\hline \multirow{2}{*}{ Examinee gender } & Male & 65 & \multirow{2}{*}{$=90$} & 720 \\
\hline & Female & 25 & & $28 \%$ \\
\hline \multirow{2}{*}{ Age } & $\leq 30$ & 38 & \multirow{2}{*}{$=90$} & $42 \%$ \\
\hline & $>30$ & 52 & & $58 \%$ \\
\hline \multirow{4}{*}{ Usage of any kind of eye aid? } & No & 47 & \multirow{4}{*}{$=90$} & $51 \%$ \\
\hline & Eye lenses & 6 & & $7 \%$ \\
\hline & Artificial tears & 5 & & $6 \%$ \\
\hline & Eyeglasses & 32 & & $36 \%$ \\
\hline \multirow{5}{*}{$\begin{array}{l}\text { Average time spent in front of the display } \\
\text { terminal }\end{array}$} & $2 \div 4 \mathrm{~h}$ & 16 & \multirow{5}{*}{$=90$} & $18 \%$ \\
\hline & $4 \div 6 \mathrm{~h}$ & 18 & & $20 \%$ \\
\hline & $6 \div 8 \mathrm{~h}$ & 15 & & $17 \%$ \\
\hline & $8 \mathrm{~h}$ & 15 & & $17 \%$ \\
\hline & More than $8 \mathrm{~h}$ & 26 & & $28 \%$ \\
\hline
\end{tabular}


The data are quite disturbing considering the fact that more than one third of examinees spend more than a quarter of the day in front of the computer display [10].

Interesting data were obtained by analyzing the answers the examinees gave to the question regarding vision problems experienced after they spent a certain number of hours working in front of computer displays. In answering this question, the examinees could choose more than one of the offered answers, but they also had to define the time period after which the perceived problems occurred. Analysis of the data given in Table 2 indicates that $37 \%$ of the examinees did not perceive any vision problems regardless of the time spent in front of the computer. A large percentage of the examinees reported that after spending a long time in front of the display they experienced problems such as neck pain (37\%), headache
(22\%), and sleepiness (21\%). Also, the number of examinees who complained of dry eyes $(18 \%)$, focusing difficulties $(14 \%)$ and eye redness $(13 \%)$ was not negligible.

The obtained data irrevocably indicated that with increased time spent in front of the computer display there was aggravation of the perceived eyesight problems such as: dry eyes, difficulty in focusing, eye redness, excess eye watering, heavy eyelids, changed color perception, as well as other health problems such as neck pain, headache, drowsiness, etc.

The fact that as many as $63 \%$ of the respondents perceived occurrence of some of the stated problems while working in front of computer displays, is therefore alarming.

Table 2 Resultsof research on the above issues

\begin{tabular}{|l|c|c|c|c|c|c|c|c|}
\hline $\begin{array}{c}\text { Has the respondent noticed any of these } \\
\text { problems? }\end{array}$ & $2 \div 4 \mathrm{~h}$ & $4 \div 6 \mathrm{~h}$ & $6 \div 8 \mathrm{~h}$ & $8 \mathrm{~h}$ & more than $8 \mathrm{~h}$ & Total & Examinees & $\%$ \\
\hline 1. No & 9 & 5 & 5 & 2 & 12 & 33 & 90 & 37 \\
\hline 2. Flash sensitivity & 1 & 1 & 0 & 3 & 2 & 7 & 90 & 8 \\
\hline 3. Dry eyes & 2 & 3 & 4 & 5 & 2 & 16 & 90 & 18 \\
\hline 4. Increased eye watering & 0 & 4 & 0 & 0 & 3 & 7 & 90 & 8 \\
\hline 5. Eye redness & 0 & 3 & 1 & 4 & 4 & 12 & 90 & 13 \\
\hline 6. Headache & 2 & 3 & 4 & 4 & 7 & 20 & 90 & 22 \\
\hline 7. Neck pain & 6 & 7 & 4 & 5 & 11 & 33 & 90 & 37 \\
\hline 8. Sleepiness & 2 & 4 & 2 & 5 & 6 & 19 & 90 & 21 \\
\hline 9. Focusing problem & 2 & 4 & 2 & 2 & 3 & 13 & 90 & 14 \\
\hline 10. Heavy eyelids & 1 & 0 & 0 & 2 & 0 & 3 & 90 & 3 \\
\hline 11. Problems using lens & 0 & 0 & 2 & 0 & 0 & 2 & 90 & 2 \\
\hline 12. Problems in color perception & 1 & 0 & 0 & 0 & 0 & 1 & 90 & 1 \\
\hline
\end{tabular}

Although anticipated results were obtained in analyzing the data regarding age of examinees who perceived some of the defined problems (Tab. 3), i.e. that those who perceived problems belonged to the over 30 age group, it is important to note that in the group of younger respondents there was also a significant number of those who complained of some of the computer vision syndrome symptoms.

Table 3 Age of respondents who encountered problems Age of examinees who experienced vision problems

\begin{tabular}{|c|c|c|c|}
\hline \multicolumn{4}{|c|}{ (some of the symptoms) } \\
\hline \multicolumn{2}{|c|}{$\leq 30$} & \multicolumn{2}{|c|}{$>30$} \\
\hline Yes & No & Yes & No \\
\hline 12 & 26 & 20 & 32 \\
\hline
\end{tabular}

Further analyses of the data obtained in the course of the research provided additional useful results depicted in Figs. 1, 2, 3, and 4.

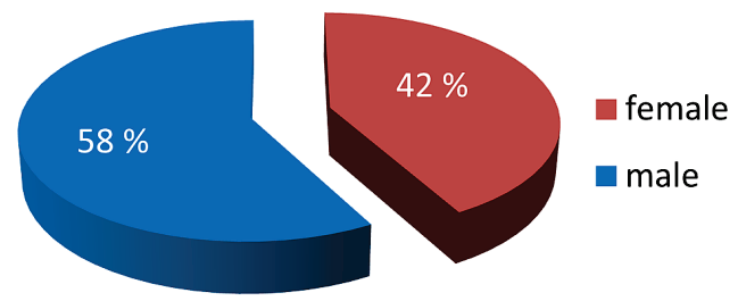

Figure 2 Overview of gender participation of examinees with CVS (Source: author's research)
Analyzing gender of the examinees who reported some of the above defined problems (Fig. 2), it was observed that the symptoms of computer eye syndrome occurred in a slightly higher percentage in males $(58 \%)$ than in females $(42 \%)$.

Despite the generated research results showed that 63 $\%$ of examinees reported one or more CVS symptoms, only $20 \%$ of the examinees have heard that this syndrome existed (Fig. 3).

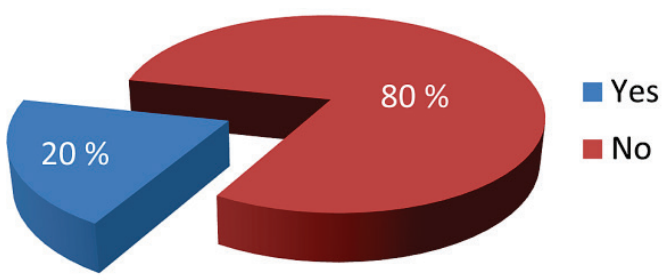

Figure 3 Number of examinees who have heard of CVS (Source: author's research)

Out of the total number of examinees who reported some of the CVS symptoms, the number of examinees who did not use any eye aids (51\%) is almost equal to the number of those using some form of eye vision aids (49\%). The analysis results (Fig. 4) indicate that it is necessary to increase awareness of computer users regarding the consequences of long-term computer use, as well as regarding the importance of using various optical aids in terms of reducing and preventing the computer eye syndrome symptoms. 
In spite of the results depicted in Fig. 4, it is important to point out that certain number of respondents who did not perceive any of the computer eye syndrome symptoms, $18 \%$ of these, decided anyway to use preventively some of the available aids. Results of this analysis are depicted in Fig. 4.

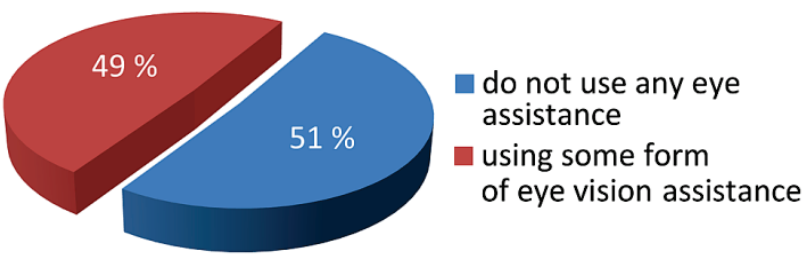

Figure 4The ratio between CVS respondents who use some eyesight aids and those who do not use any aids (Source: author's research)

Despite the results shown in Fig. 4, it is important to mention that certain number of examinees $(18 \%)$, who did not notice any of the CVS symptoms, decided to use preventive eye aids in order to protect themselves from CVS. The results of this analysis are shown in Fig. 5.

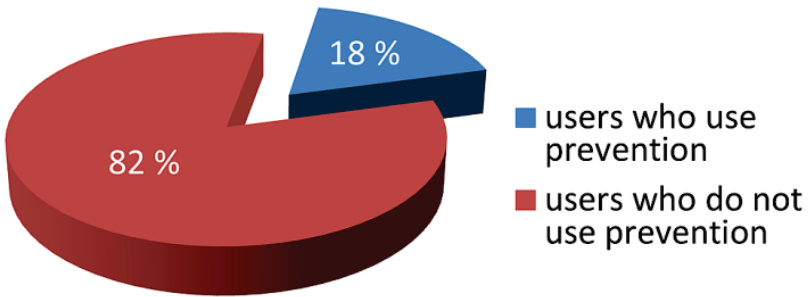

Figure 5 The ratio of the examinees who did not notice any of the CVS symptoms but used some eye aids and the examinees who did not use any kind of eye aids

(Source: author's research)

\section{CVS Prevention}

Taking into consideration the results of the research, it is obvious that there is space for improvement and therefore the following solutions should be taken into account with the aim of reducing and preventing CVS occurrence $[11,12]$.

- Fitting the screen height. If the monitor is not static, its height can be adjusted so that the center of the screen is slightly below of eye level when sitting upright.

- Adjusting the monitor light. Displays with strong reflections can also be the cause of constant tearing and eye muscles straining.

- Frequent blinking is necessary. Office environment dries the eyes additionally, so frequent blinking is needed to keep them wet.

- 10-minute breaks every two hours are recommended to rest the eyes.

- Eye muscles, like body muscles, need training or stretching, so exercising is recommended every 15 to 20 minutes. The exercise is performed by looking away from the display and making left-right eye movements, or by averting the gaze from the screen to a 20-meter distant object for at least 20 seconds.

\section{Conclusion}

Eye and vision problems are frequent health issues among engineers and other users who spend a lot of time in front of computer display screens which can lead to reduced productivity, higher error rates, frequent sick leaves and diminished job satisfaction. This study showed the problems encountered by the users, and this was something to be expected. What is worrying, however, is the poor awareness of the above mentioned problems and of the ways for their prevention. Similar problems related to the impairment of work ability in other professions are better regulated (ie. drivers with mandatory breaks after a certain period of time) which is not the case for activities that require prolonged sitting at the computer. Bearing this in mind, prevention is still the preferred strategy.

On the basis of these observations, it is necessary to take actions aimed at educating users and employers of the ways to reduce the CVS related health issues. It is essential for companies to develop a plan to mitigate the impact of the syndrome on their employees, as well as to the entire businesses. In practical terms the results of this research could be used used in education, and hence in prevention. Recommendations made in this paper should help individuals and employers to define guidelines to improve the health and productivity of their employees. This syndrome includes spine problems as well, but these have not been analyzed in this paper, due to the fact that users are familiar with this problem and, unlike in the case of CVS, they have already taken adequate preventive measures. The measures for preventing and remedying the CVS problems often involve making breaks, applying proper lighting, exercises, using ergonomic chairs and optical aids.

\section{Future work}

In future, the same research will be conducted in the EU countries and comparison between the obtained results will be made, trying to determine where Serbia stands with respect to the EU regarding CVS. We also want to gather foreign experiences in fighting development of this syndrome and to transfer this knowledge to our country.

\section{Acknowledgement}

The authors want to take this opportunity to thank all the research participants for their dedicated time, with the hope that these results will draw more attention of computer users to the CVS and be generally helpful to them, so that much less CVS problems will be recorded in future research studies.

\section{References}

[1] Rosenfield, M.; Gurevich, R.; Wickware, E.; Lay, M. Computer Vision Syndrome: Accommodative \& Vergencedacility. // Journal of Behavioral Optometry. 21, 5(2010), pp. 119-122.

[2] Sen, A.; Richardson, A. A Study of Computer related Upper Limb Discomfort and Computer Vision Syndrome. // J. Human Ergol. 36, (2007), pp. 45-50. 
[3] Divjak, M.; Bischof, H. Eye blink based fatigue detection for prevention of Computer Vision Syndrome. // IAPR Conference on Machine Vision Applications, May 20-22, Yokohama, Japan, 2009.

[4] Abelson, M. B.; Ousler III, G. W. How to Fight Computer Vision Syndrome. // Review of Ophthalmology. July 1999.

[5] Chiemeke S. C.; Akhahowa, A. E.; Ajayi, O. B. Evaluation of Vision-Related Problems amongst Computer Users: A Case Study of University of Benin, Nigeria. // Proceedings of the World Congress on Engineering 2007 Vol I, WCE 2007, July 2 - 4, 2007, London, U. K.

[6] Wimalasundera, S. Computer vision syndrome. // Galle Medical Journal. 11, 1(2006).

[7] Charpe, N. A.; Kaushik, V. Computer Vision Syndrome (CVS): Recognition and Control in Software Professionals. // J Hum Ecol. 28, 1(2009), pp. 67-69.

[8] Rahman, Z. A.; Sanip, S. Computer User: Demographic and Computer Related Factors that Predispose User to Get Computer Vision Syndrome. // International Journal of Business, Humanities and Technology. 1, 2(2011).

[9] Singh, S.; Wadhwa, J. Impact of Computer Workstation Design on Health of the Users. // J. Hum. Ecol. 20, 3(2006), pp. 165-170.

[10] Mohamed Ali, K.; Sathiyasekaran, B. W. C. Computer Professionals and Carpal Tunnel Syndrome (CTS). // International Journal of Occupational Safety and Ergonomics (JOSE). 12, 3(2006), pp. 319-325. DOI: 10.1080/10803548.2006.11076691

[11] Loh, K. Y.; Reddy, S. C. Understanding and Preventing Computer Vision Syindrome. // Malaysian Family Physician. 3, 3(2008), Academy of Family Physicians of Malaysia, Online version: www.ejournal.afpm.org.my.

[12] Wimalasundera, S. Computer vision syndrome. // Galle Medical Journal. 11, 1(2006).

\section{Authors' addresses}

\section{MSc Dejan Viduka, PhD student}

Faculty of Technical Sciences,

Singidunum University

Danijelova 32, 11000 Belgrade, Serbia

dejan@viduka.info

MSc Marina Dragičević, PhD student

Clinical center Vojvodine - Novi Sad

Hajduk Veljkova 1, 21000, Serbia

drmakica@gmail.com

MSc Ana Bašić, PhD student

Faculty of Technical Sciences, Singidunum University

Danijelova 32, 11000 Belgrade, Serbia

basic.ana22@gmail.com

\section{MSc Biljana Viduka, PhD student}

Technical College of Applied Sciences - Zrenjanin Đorđa Stratimirovića 23, 23000 Zrenjanin, Serbia

biljana@viduka.info

\section{MSc Igor Lavrnić, PhD student}

Faculty of Technical Sciences,

Singidunum University

Danijelova 32, 11000 Belgrade, Serbia

ilavrnic@yahoo.com 